\title{
The impact of the European Directive 2014/95/EU on the energy companies' disclosures
}

\author{
Valentin-Florentin DUMITRU \\ The Bucharest University of Economic Studies, Bucharest, Romania \\ valentin.dumitru@cig.ase.ro \\ Gabriel JINGA \\ The Bucharest University of Economic Studies, Bucharest, Romania \\ gabriel.jinga@cig.ase.ro \\ Oana Georgiana STĂNILĂ \\ The Bucharest University of Economic Studies, Bucharest, Romania \\ oana.stanila@cig.ase.ro \\ Mădălina DUMITRU \\ The Bucharest University of Economic Studies, Bucharest, Romania \\ madalina.dumitru@cig.ase.ro
}

\begin{abstract}
Even though the sustainability reporting is voluntary, companies are increasingly adopting it. There is a multitude of reporting standards used by companies in this regard. Along with the voluntary guidelines, in 2014 was adopted a European Directive which became mandatory for a set of companies. Our research question is which are the changes brought in the reporting of the European companies by the Directive? In doing this, we focus on the energy companies. We selected them because they are environmentally-sensitive. We selected the European energy companies which included a report for last year in the GRI's database. We downloaded the reports published by the sample companies in the period 2014 - 2017. We selected 2014 as a starting point because it is the year in which the Directive was approved. We selected 2017 because it was the first year in which the ED 2014/95/EU became mandatory. First of all, we extracted the words used in the Directive for writing the names of the indicators. Using NVivo Pro, we searched for the indicators in the selected reports. By analyzing the core indicators for the energy domain, we pursued to identify the sample companies' commitment to sustainability. The contribution of our study is that it provides an insight into the Directive as a driver which influences the sustainability reporting.
\end{abstract}

Keywords: energy, sustainability reporting, Europe, key performance indicators

\section{Introduction}

The sustainability concerns became a constant in our lives during the last decades. As such, entities report increasingly on sustainability issues. In order to do so, they adopted in the beginning a voluntary approach. As the number of reports increased, there was a need for guidelines. The first was represented by the Triple Bottom Line (Elkington, 1997). The most important body created in this regard is the Global Reporting Initiative (GRI). The guidelines released by the GRI reached the fourth generation and are now the most used in the area of sustainability reporting. In the third step, the authorities started to acknowledge the importance of the sustainability reporting for the stakeholders and issued regulations. Thus, there are countries (such as the ones included in the European Union - EU) in which certain aspects of this form of reporting became mandatory. 
The most active region in the world in terms of the sustainability reporting is Europe (Wagner, 2018). The European Directive 2014/95/EU (the Directive) became mandatory for the large undertakings in 2017 and the first reports applying it were published in 2018. However, Europe is a diverse continent, in which the countries are still preserving their culture. Thus, our research question is which are the changes brought in the reporting of the European companies by the Directive? In doing this, we focus on the energy companies. We selected them because they are environmentally-sensitive. Previous evidence (Dumitru et al., 2017; Avram et al., 2018; Barbu et al., 2014) shows that the environmentally-sensitive companies tend to report more. We adopted the following approach: first, we extracted the words used in the Directive for writing the names of the indicators. Using NVivo Pro, we searched for the indicators in the selected reports. We selected from the GRI database the large European energy companies which included their reports in 2018 (published for 2017) in the database. By analyzing the core indicators for the energy domain, we pursued to identify the sample companies' commitment to sustainability. We consider that sustainability reporting is a driver of the embedment of sustainability into the organization. How much of what a company reports on (even observing the requirements of the Directive) is actually directed to the decrease in the unsustainability?

Our paper is structured as it follows: first, we present the literature review. The research methodology follows. The paper continues with the research results and ends with the discussion and conclusions of our study.

\section{Literature review}

A timeline of the EU's initiatives in respect of the corporate social responsibility (CSR) reporting is presented in table 1.

Table 1. EU's initiatives regarding the CSR reporting

\begin{tabular}{|l|l|l|}
\hline Year & \multicolumn{1}{|c|}{ Name } & \multicolumn{1}{c|}{ Most important requirements } \\
\hline 1995 & $\begin{array}{l}\text { Eco-Management } \\
\text { and Audit Scheme }\end{array}$ & $\begin{array}{l}\text { It is designed to help "organisations to evaluate, report, and improve their } \\
\text { environmental performance." }\end{array}$ \\
\hline 2000 & $\begin{array}{l}\text { EU Financial } \\
\text { Reporting Strategy: } \\
\text { The Way Forward }\end{array}$ & $\begin{array}{l}\text { "Where appropriate, an analysis of environmental and social aspects } \\
\text { necessary for an understanding of the company's development, performance } \\
\text { or position" should be disclosed }\end{array}$ \\
\hline 2003 & $\begin{array}{l}\text { Accounts } \\
\text { Modernization }\end{array}$ & $\begin{array}{l}\text { "The information should not be restricted to the financial aspects of the } \\
\text { company's business. It is expected that, where appropriate, this should lead } \\
\text { to an analysis of environmental and social aspects necessary for an } \\
\text { understanding of the company's development, performance or position." }\end{array}$ \\
\hline 2006 & $\begin{array}{l}\text { Directive } \\
\text { "Companies whose securities are admitted to trading on a regulated market } \\
\text { and which have their registered office in the Community should be obliged } \\
\text { to disclose an annual corporate governance statement as a specific and } \\
\text { clearly identifiable section of the annual report." }\end{array}$ \\
\hline 2014 & $\begin{array}{l}\text { Directive } \\
2014 / 95 / \mathrm{EU}\end{array}$ & $\begin{array}{l}\text { "Large undertakings which are public-interest entities exceeding on their } \\
\text { balance sheet dates the criterion of the average number of 500 employees } \\
\text { during the financial year shall include in the management report a non- } \\
\text { financial statement containing information to the extent necessary for an } \\
\text { understanding of the undertaking's development, performance, position and } \\
\text { impact of its activity, relating to, as a minimum, environmental, social and } \\
\text { employee matters, respect for human rights, anti-corruption and bribery } \\
\text { matters" }\end{array}$ \\
\hline
\end{tabular}

Source: authors' compilation 
The Directive 2014/95/EU is the first to ask for mandatory reporting from a set of companies. Its appearance was motivated by the need to improve the comparability and the transparency of the information reported on CSR. The European Commission has the drive to foster the area of renewable energy and to build an Energy Union (Șanta, A.-M.I., 2017). The companies are required to present their business model, the policies and the due diligence processes implemented in regard of the environmental and social aspects, the outcome of the policies and the main risks. The disclosure should include the appropriate key-performance indicators. The information can be presented in the annual report or, if the company already prepares a CSR report, in the CSR report.

The research conducted so far on the Directive is dedicated to: the requirements of the Directive and its transposition in several European countries (e.g. Poland, UK, France, Italy), its application in specific countries (e.g. Italy, Poland, Romania) or in specific industries (e.g. oil and gas industry), the reporting of several indicators (e.g. human rights).

A few authors analysed the Directive and its transposition in the European countries. Wagner (2018) analyses the Directive from several points of view: the meaning of CSR and the rationale for the use of non-financial reporting (NFR); development trends of NFR; the development of NFR in Europe; the challenges of implementing the Directive in the Member States such as France and Denmark; critique of the Directive. She concludes that the Directive represents a point forward in the evolution of the NFR, but it won't bring a better reporting because of: limited coverage of enterprises; lack of uniform reporting standards; too much flexibility given to covered businesses; lack of strong verification requirements; lack of strong penalties or other remedies for disclosure violations.

According to Barcik and Dziwinski (2015) "the provisions of the Directive 2014/95/EU are the result of a compromise between the countries that are more advanced in terms of CSR reporting (such as Denmark and France) and those which have so far implemented the minimum requirements regarding non-financial disclosures (such as Poland, Germany, or the Czech Republic)."

Aureli et al. (2018) study the transposition of the Directive in UK, France and Italy. Their analysis shows that there are significant differences at country level, which can hamper the purpose of the Directive to obtain similar level of company's transparency on social and environmental matters, increasing trust and encouraging more sustainable behaviours. According to the authors the "sub-objectives" of transparency are: completeness, relevance, clarity, comparability, consistency, timeliness. The sub-objectives of trust are: reliability and accuracy. The sub-objectives of change in CSR practices are enforcement and board involvement.

Bernardi and Stark (2017) prove that there is a demand regarding the disclosures imposed by the Directive from informed market participants, such as the analysts. The demand is taken into account by the managers, when establishing the amount of social and environmental disclosures.

The situation in Poland was explored in several articles. Matuszak and Rozanska (2017) analyse the transposition of the Directive in Poland and the reporting practices of the Polish companies. The conclusion is that the preferred disclosure tool is the annual report, the companies do not report on all the items required, especially about human rights and anti-corruption. Dyduch and Krasodomska (2017) identified significant influence exercised 
on CSR disclosures by industry environmental sensitivity, company turnover, duration of the stock exchange listing, inclusion in the Respect Index portfolio and foreign capital share. Maj et al. (2018) study the determinants of the social and environmental reporting, which can act in the case of the implementation of the Directive. The determinants are grouped into three categories: company characteristics (e.g. size, leverage, performance, presence on foreign markets, media visibility, ownership structure, research and development expenditures industry, age of assets), general contextual factors (e.g. country, public pressure, specific concerns of specific stakeholders) and internal contextual factors (e.g. corporate executives attitudes towards CSR disclosure). They applied a CATI research on the companies listed at the Warsaw Stock Exchange. Their conclusion was different from the one reached by Dyduch and Krasodomska (2017) as they could not identify institutional factors influencing the sustainability disclosure. Still, there are many disparities in convergence between a country from Central and Eastern Europe (Dima, MA., Vasilache, S., 2016).

Dumitru et al. (2017) studied the degree of preparation of the companies in Poland and Romania for the implementation of the Directive. They established that the companies were prepared for the implementation in a small degree and that they were doing better in the area in which traditionally the country had bigger issues (environmental area in Poland and social area in Romania). According to this study, regulation, local institutional characteristics, ownership, industry and auditors have an impact on the quality of disclosures.

Venturelli et al. (2017) analyse the reporting of 223 large Italian companies using a non-financial information score. An information gap exists in Italy as well. This indicates that the contribution of the implementation of the Directive in the analysed countries could be important.

Carini et al. (2018) investigate the content of the companies' reports with reference to the requirements of the Directive and the information overlapping in the annual and CSR reports. They select the companies operating in the oil and gas industry. They find a higher degree of compliance of the reports with the Directive than in Romania and Poland (Dumitru et al., 2017; Dyduch and Krasodomska, 2017) and lower than in Italy (Venturelli et al., 2017), homogeneous information in the CSR reports (prepared according to the GRI guidelines) and heterogeneous CSR information in the annual reports. The CSR reports are preferred for the communication of non-financial information by this set of companies, as opposed to the annual report used by the Polish companies (Matuszak and Rozanska, 2017).

Gaztea and Fernandez (2017) present the implications of the Directive in respect of the human rights.

La Torre et al. (2018) suggest a future research agenda starting from the Directive. The identified research themes refer to supranational and national regulators, undertakings, standard-setters and auditors.

In conclusion, there are articles which analyse the correlations, the quality of the reporting, the transposition of the Directive in different countries, compare the Directive with other frameworks (such as the GRI or the IIRF). We did not find qualitative studies, based on the cases of the companies which actually report information based on the Directive. This is the approach that we adopt in our research. 


\section{Methodology}

Our research question is which are the changes brought in the reporting of the European companies by the Directive? We selected the large European companies in the energy sector. We started from the GRI database on October 22, 2018. We applied the following selection criteria: large companies, energy, Europe, 2018. It resulted a number of 21 companies. Yet, six of them did not publish reports in English. So, we continued with 15 companies, for which we downloaded the reports published for 2014-2017. In total, we downloaded and analysed 67 reports. These were either CSR reports or annual/integrated reports which included CSR information.

Our paper is based on content analysis. We used NVivo for the data analysis. First, we introduced in NVivo the Directive. We obtained a list with the words used in the Directive. In total, we extracted 37 terms. The words were grouped on the main categories of disclosures required by the Directive 2014/95/EU:

- Business model, policies, risks related to CSR issues;

- Environmental matters;

- Social and employee related matters;

- Ethical matters.

Afterwards, we analysed the presence of the selected words in the reports. We uploaded in NVivo the reports published by the selected companies in the period 2014-2017. We compared the use of the terms within the categories mentioned above.

\section{Results and discussions}

The frequency of the words which are related with the requirements of the Directive 2014/95/EU used in the reports disclosed by the companies included in our sample for the investigated period are presented in table 1.

Table 1. Frequency of the words used in the annual reports

\begin{tabular}{|c|c|c|c|c|}
\hline Word NFR & $\begin{array}{c}\text { Frequency } \\
2014\end{array}$ & $\begin{array}{c}\text { Frequency } \\
2015\end{array}$ & $\begin{array}{c}\text { Frequency } \\
2016\end{array}$ & $\begin{array}{c}\text { Frequency } \\
2017\end{array}$ \\
\hline No of reports & 16 & 15 & 19 & 17 \\
\hline \multicolumn{5}{|c|}{ Business model, policies, risks related to CSR issues } \\
\hline Business & 110.00 & 128.67 & 109.79 & 119.59 \\
\hline \multicolumn{5}{|c|}{ Environmental matters } \\
\hline Air & 10.31 & 7.53 & 8.42 & 10.65 \\
\hline Emissions & 42.56 & 47.27 & 47.11 & 48.29 \\
\hline Energy & 91.31 & 107.93 & 109.37 & 106.53 \\
\hline Environment & 35.31 & 36.13 & 39.53 & 37.06 \\
\hline Environmental & 80.75 & 76.20 & 80.53 & 78.06 \\
\hline GHG & 6.06 & 7.20 & 7.95 & 9.71 \\
\hline Impacts & 46.88 & 51.00 & 51.16 & 49.53 \\
\hline KPIs & 22.56 & 24.53 & 20.74 & 23.41 \\
\hline Policies & 43.38 & 50.00 & 50.05 & 50.82 \\
\hline Pollution & 0.00 & 0.00 & 0.00 & 0.00 \\
\hline
\end{tabular}




\begin{tabular}{|c|c|c|c|c|}
\hline Prevention & 7.06 & 8.47 & 7.89 & 8.47 \\
\hline Protection & 31.63 & 28.47 & 26.47 & 25.71 \\
\hline Renewable & 7.94 & 1.00 & 7.32 & 11.24 \\
\hline Water & 37.25 & 39.27 & 40.21 & 38.53 \\
\hline \multicolumn{5}{|c|}{ Social and employee related matters } \\
\hline Communities & 46.31 & 45.67 & 39.37 & 39.53 \\
\hline Dialogue & 0.00 & 0.00 & 0.00 & 0.00 \\
\hline Employee & 122.88 & 126.33 & 108.42 & 121.71 \\
\hline Equality & 0.00 & 0.00 & 0.00 & 0.00 \\
\hline Gender & 5.56 & 8.60 & 7.53 & 8.65 \\
\hline Health & 29.13 & 33.87 & 30.53 & 34.47 \\
\hline Human & 18.19 & 23.73 & 19.68 & 20.59 \\
\hline Labour & 6.56 & 14.33 & 18.37 & 17.29 \\
\hline Right & 31.75 & 38.80 & 40.95 & 38.53 \\
\hline Risks & 102.94 & 141.80 & 131.74 & 135.24 \\
\hline Safety & 48.69 & 58.93 & 58.74 & 56.41 \\
\hline Social & 31.06 & 36.40 & 37.16 & 32.65 \\
\hline Trade-union & 7.38 & 8.33 & 7.84 & 0.00 \\
\hline Work & 47.38 & 51.13 & 46.00 & 47.29 \\
\hline Workers & 6.25 & 15.20 & 12.79 & 6.12 \\
\hline Working & 20.06 & 26.67 & 25.53 & 23.24 \\
\hline \multicolumn{5}{|c|}{ Ethical matters } \\
\hline Abuses & 0.00 & 0.00 & 0.00 & 0.00 \\
\hline Actions & 23.19 & 41.33 & 25.16 & 26.94 \\
\hline $\begin{array}{l}\text { Anti- } \\
\text { corruption }\end{array}$ & 8.13 & 9.87 & 10.11 & 13.18 \\
\hline Bribery & 0.00 & 0.00 & 0.00 & 0.00 \\
\hline Ethical & 15.19 & 11.13 & 6.68 & 8.18 \\
\hline Fight & 0.00 & 0.00 & 0.00 & 0.00 \\
\hline Total & $1,143.63$ & $1,305.80$ & $1,233.11$ & $1,247.59$ \\
\hline
\end{tabular}

Source: Authors' own research using NVivo. We notice that the increase in the use of the key-words in the selected reports is not significant. So, a conclusion is that the companies did not prepare for the implementation of the Directive during the four available years. There are key-words (such as pollution, dialogue, bribery) which do not appear at least once in the reports.

The biggest increase was registered for the word "labour", of 2.64 times. The word "trade-union" was not presented at all in the reports published for 2017. 23 words were more frequently used in 2017 as compared with 2014. For seven words the reporting frequency decreased during the analysed period. "risk".

The most used word in 2014 was "employee", while the most used word in 2017 was 
While there is an increase in the use of the key terms during the period analysed, we notice that the increase is of only $9 \%$. In the same time, we notice that the year with the maximum disclosure of the key-words is 2015.

A synthesis of the results is included in table 2.

Table 2. Synthesis of the results

\begin{tabular}{|c|c|c|c|c|c|}
\hline Item & 2014 & 2015 & 2016 & 2017 & Total \\
\hline \multicolumn{6}{|c|}{ Business model, policies, risks related to CSR issues } \\
\hline Average $/ \mathrm{mim} / \max$ & 110.00 & 128.67 & 109.79 & 119.59 & 468.05 \\
\hline \multicolumn{6}{|c|}{ Environmental matters } \\
\hline Average & 33.07 & 34.64 & 35.48 & 35.57 & 138.76 \\
\hline Min & 0.00 & 0.00 & 0.00 & 0.00 & 0.00 \\
\hline Max (energy) & 91.31 & 107.93 & 109.37 & 106.53 & 415.14 \\
\hline \multicolumn{6}{|c|}{ Social and employee related matters } \\
\hline Average & 32.76 & 39.36 & 36.54 & 36.36 & 145.02 \\
\hline Min & 0.00 & 0.00 & 0.00 & 0.00 & 0.00 \\
\hline Max (risks) & 102.94 & 141.80 & 131.74 & 135.24 & 511.72 \\
\hline \multicolumn{6}{|l|}{ Ethical matters } \\
\hline Average & 7.75 & 10.39 & 6.99 & 8.05 & 33.18 \\
\hline Min & 0.00 & 0.00 & 0.00 & 0.00 & 0.00 \\
\hline Max (actions) & 23.19 & 41.33 & 25.16 & 26.94 & 116.62 \\
\hline
\end{tabular}

Source: Authors' own research using NVivo.

We notice that the most disclosed indicators are included in the Business model, policies, risks related to CSR issues category, followed by Social and employee related matters. They registered a slow increase during the analysed period.

\section{Conclusion}

There is a great deal of literature and in the same time a great deal of talks regarding the sustainability. However, so far the reporting of these issues is not comparable and consistent. In our research, we started from the idea that the implementation of the Directive 2014/95/EU will bring a new face to the CSR reporting in Europe.

We selected in our study the energy companies. This is an environmentally-sensitive domain and we considered that these companies will prepare better for the implementation of the directive.

Our results show that there was a small increase in the use in the annual reports of the key-words included in the directive after its adoption. Also, the year in which the words were the most frequently used was 2015. There are still aspects required by the directive (such as pollution, equality, bribery), which are not presented at all. This shows that the Directive can have a positive impact on the reporting of these companies and supports the conclusion of Venturelli et al. (2017), but in the first year of its application it did not bring a better reporting, as forecasted by Wagner (2018). In the same time, the fact that some aspects are better presented than others by the companies shows that there are other drivers of the 
reporting as well and that the requirements of the Directive are not enough. This finding is in line with the one of Avram et al. (2018).

Even though the selected companies were included in the energy domain, the environmental key-performance indicators are not the most disclosed. These are the indicators included in the business model, policies, risks related to CSR issues. Also, the most disclosed indicators are employee in 2014 and risk in 2017.

Our study shows that there is still need for the improvement of the CSR reporting in Europe. The finding is in line with the one reported by the Matuszak and Rozanska (2017).

\section{References}

Aureli, S., \& Magnaghi, E. \& Salvatori, F. (2018). The transposition of the non-financial reporting directive in the UK, France and Italy. Symphonya. Emerging Issues in Management (symphonya.unimib.it), 1, 48-67.

Avram, V., \& Calu, D.A., \& Dumitru, V.F., \& Dumitru, M., \& Glăvan, M.E., \& Jinga, G. (2018). The institutionalization of the consistency and comparability principle in the European companies. Energies, 11(12), 3456.

Barbu, E., \& Dumontier, P., \& Feleagă, N., \& Feleagă, L. (2014). Mandatory environmental disclosures by companies complying with IASs/IFRSs: the cases of France, Germany, and the UK. International Journal of Accounting, 49, 231-247.

Barcik, A., \& Dziwinski, P. (2015). Relations with employees in CSR strategies at Polish enterprises with regard to compliance mechanism. Responsible Sustainability, 3, 1326.

Bernardi, C., \& Stark, A.W. (2017). The value relevance of environmental and social disclosures - evidence from the UK stock market. Retrieved from https://www.researchgate.net/publication/320617905_THE_VALUE_RELEVANCE_OF _ENVIRONMENTAL_AND_SOCIAL_DISCLOSURES__EVIDENCE_FROM_THE_UK_STOCK_MARKET.

Carini, C., \& Rocca, L., \& Veneziani, M., \& Teodori, C. (2018). Ex-ante impact assessment of sustainability information - the Directive 2014/95. Sustainability, 10(2), 560.

Dima, M.A. and Vasilache, S. (2016), "Trends in the internationalization of European higher education in a convergence perspective", Management \& Marketing. Challenges for the Knowledge Society, Vol. 11, No. 2, pp. 449-457 D0I: 10.1515/mmcks2016-0008.

Dumitru, M., \& Dyduch, J., \& Gușe, R.G. \& Krasodomska, J. (2017). Corporate reporting practices in Poland and Romania - an ex-ante study to the new non-financial reporting European Directive. Accounting in Europe, 14(3), 279-304.

Dyduch, J., \& Krasodomska, J. (2017). Determinants of corporate social responsibility disclosure: an empirical study of Polish listed companies, Sustainability, 9(11), 1934.

EU (European Union) (2014). Directive 2014/95/EU of the European Parliament and of the Council of 22 October 2014 amending Directive 2013/34/EU as regards disclosure of non-financial and diversity information by certain large undertakings and groups. Retrieved from http://eur-lex.europa.eu/legalcontent/EN/TXT/PDF/?uri=OJ:L:2014:330:FULL\&from=EN.

EC (European Commission) (2000). Communication from the Commission to the Council and the European Parliament: EU Financial Reporting Strategy: the way forward. 
Retrieved

from

http://eurlex.europa.eu/LexUriServ/LexUriServ.do?uri=COM:2000:0359:FIN:EN:PDF.

EC (European Commission) (2003). European Council and Parliament Directive no. 2003/51/EC (Accounts Modernization Directive). Retrieved from http://eurlex.europa.eu/LexUriServ/LexUriServ.do?uri=0J:L:2003:178:0016:0022:en:PDF.

EC (European Commission) (2006). European Council and Parliament Directive no. 2006/46/EC. $\quad$ Retrieved from http://eurlex.europa.eu/LexUriServ/LexUriServ.do?uri=0J:L:2006:224:0001:0007:EN:PDF.

La Torre, M., \& Sabelfeld, S., \& Blomkvist, M., \& Tarquinio, L., \& Dumay, J. (2018). Harmonising non-financial reporting regulation in Europe: Practical forces and projections for future research. Meditari Accountancy Research, 26(4), 598-621.

Maj, J., \& Hawrysz, L., \& Bębenek, P. (2018). Determinants of corporate social responsibility disclosure in Polish organisations. International Journal of Contemporary Management, 17(1), 197-215.

Matuszak, Ł., \& Różańska, E. (2017). CSR disclosure in Polish-listed companies in the light of Directive 2014/95/EU requirements: empirical evidence. Sustainability, 9(12), 2304.

Șanta, A.-M.I. (2017), "The Common Energy Market of the European Union - Challenges and Perspectives", Management and Marketing. Challenges for the Knowledge Society, Vol. 12, No. 2, pp. 334-345. DOI 10.1515/mmcks-2017-0020.

Venturelli, A., \& Caputo, F., \& Cosma, S., \& Leopizzi, R., \& Pizzi, S. (2017). Directive 2014/95/EU: are Italian companies already compliant? Sustainability, 9(8), 1385.

Wagner, C.Z. (2018). Evolving norms of corporate social responsibility: lessons learned from the European Union Directive on non-financial reporting. Transactions: Tennessee Journal of Business Law, 19, 619. 